\title{
ANALISIS MORFOMETRIK DAN SIFAT KUALITATIF WARNA BULU PADA PUYUH LIAR (Turnix suscitator atrogularis) DAN PUYUH DOMESTIKASI (Coturnix-coturnix japonica)
}

\author{
(Morphometrics Analysis And Characteristic of Colour Feathers The Wild (Turnix suscitator \\ atrogularis) and Domestication (Coturnix-coturnix japonica) Quail)
}

\author{
Reynal Parasian Hutagalung ${ }^{1}$, Hamdan $^{2}$ Dan Zulfikar Siregar ${ }^{2}$ \\ 1. Mahasiswa Program Studi Peternakan Fakultas Pertanian Universitas Sumatera Utara \\ 2. Staf pengajar Program Studi Peternakan Fakultas Pertanian Universitas Sumatera Utara
}

\begin{abstract}
Research of morphological, morphometric, and the qualitative nature of colour feathers is the basis process of selection and breeding quail. This research aims to identify the main identifier on the size and shape of wild quail and qualitative traits of wild quail feather and domestication. This research used 20 wild quail and 20 domestication quail . Data were analyzed using Principal Component Analysis and Software Statistical Package for Social Science (SPSS) to determine the identifier the size and shape of organs both types of quail.The results showed that the primary identifier on the size of the external organs of wild quail is the longest fingers and organs form outside the main identifier is the length of the wing. The main identifier is the length of organ size in the small intestine and the main identifier is the long form of the mouth and neck. The main identifier the size of the outer parts of quail domestication is the length of the femur and tibia. The main identifier is the long form of the outer parts maxilla. The main identifier is the size of the organ in the liver and the identifier is the main form of long necks. Characteristic of the colour feathers wild quail is very different with domesticated. Wild quail males have yellowish brown neck, while the females are black. Male domesticated quail have dark brown neck, while the female is light brown. Wild quail has a beak and feet are gray while quail domestication has a yellow beak and feet.
\end{abstract}

Keywords : Quail, morphology, morphometrics, the qualitative nature.

\section{ABSTRAK}

Tinjauan terhadap morfologi, morfometrik, dan sifat kualitatif warna bulu merupakan dasar di dalam proses seleksi dan pemuliaan burung puyuh. Penelitian ini bertujuan mengidentifikasi penciri utama ukuran dan bentuk serta sifat-sifat kualitatif warna bulu burung puyuh liar (Turnix suscitator atrogularis) dan domestikasi. Burung puyuh domestikasi yang diteliti sebanyak 20 ekor dan burung puyuh liar yang diteliti sebanyak 20 ekor. Data dianalisis menggunakan Analisis Komponen Utama dengan bantuan Software Statistical Package for the Social Science (SPSS) untuk menentukan penciri utama ukuran dan bentuk organ tubuh kedua jenis burung puyuh. Hasil penelitian menunjukkan bahwa penciri utama ukuran organ luar pada burung puyuh liar adalah jari ketiga dan penciri utama bentuk organ luar adalah panjang sayap. Penciri utama ukuran organ dalam adalah panjang usus halus dan penciri utama bentuk adalah panjang mulut dan leher. Penciri utama ukuran organ luar pada burung puyuh domestikasi adalah panjang femur dan tibia. Penciri utama bentuk organ luar adalah panjang maxilla. Penciri utama ukuran organ dalam adalah organ hati dan penciri utama bentuk adalah panjang leher. Sifat-sifat kualitatif warna bulu pada kedua jenis burung puyuh sangat berbeda. Puyuh liar jantan memiliki leher berwarna cokelat kekuningan, sedangkan leher pada betina berwarna hitam. Puyuh domestikasi jantan memiliki leher berwarna cokelat tua sedangkan leher pada betina berwarna cokelat muda. Puyuh liar memiliki paruh dan kaki berwarna abu-abu sedangkan puyuh domestikasi memiliki paruh dan kaki berwarna kuning.

Kata kunci : Puyuh, morfologi, morfometrik, sifat kualitatif. 


\section{PENDAHULUAN}

Burung puyuh adalah salah satu jenis burung yang hidup secara liar dan keberadaannya di alam bebas dan terbuka. Burung ini biasanya ditemukan dengan cara diburu di hutan-hutan pedalaman. Puyuh liar biasanya hidup di semak-semak pinggir hutan dan padang rumput. Puyuh ini dapat diburu dengan leluasa karena merupakan burung yang mudah berkembang biak. Hal ini ditandai dengan produksi telurnya yang banyak dan sifatnya yang pandai mengeram (Insani, 2007)

Puyuh biasa dikenal dengan nama gemak, gemak ini masih bisa ditemukan di sawah atau ladang yang ditanami palawija sehingga sering juga diburu oleh pemburu liar untuk diambil telur atau dagingnya. Seiring dengan perkembangan jaman, burung puyuh telah mengalami domestikasi dan telah diternakkan oleh manusia secara komersil untuk menghasilkan daging dan telurnya. Rasa khas burung ini menjadikan daging puyuh memiliki penggemar tersendiri, begitu pula rasa telurnya yang tidak dapat disamakan dengan telur ayam biasa.

Pertambahan jumlah penduduk yang semakin pesat di Indonesia dewasa ini menyebabkan semakin meningkatnya kebutuhan akan konsumsi makanan. Ternak unggas seperti halnya burung puyuh memegang peranan yang penting di dalam penyediaan protein hewani bagi manusia sehingga pengembangannya harus benar-benar diperhatikan dan terus ditingkatkan.

Beberapa usaha yang penting untuk dilakukan adalah seleksi dan pemuliaan puyuh. Tujuan dari seleksi adalah mendapatkan bibit-bibit puyuh yang baik dan unggul yang kelak dapat meningkatkan produksi dari segi kualitas dan kuantitas. Pengetahuan tentang morfologi dan morfometrik, serta sifat kualitatif warna bulu adalah beberapa aspek yang perlu diketahui oleh peternak dan instansi-instansi terkait karena menjadi acuan di dalam melakukan seleksi burung puyuh.

\section{BAHAN DAN METODE}

\section{Lokasi dan Waktu Penelitian}

Penelitian ini dilaksanakan di Laboratorium Biologi Ternak Fakultas Pertanian Universitas Sumatera Utara pada bulan Juni tahun 2012. 


\title{
Bahan dan Alat
}

\section{Bahan}

Puyuh Liar (Turnix suscitator atrogularis) jantan sebanyak 10 ekor dan betina sebanyak 10 ekor berasal dari desa Percut, Kecamatan Percut Sei Tuan, Kabupaten Deli Serdang. Puyuh domestikasi jantan sebanyak 10 ekor dan yang betina sebanyak 10 ekor diperoleh dari pusat penjualan aneka burung di Jalan Bintang, Medan.

\begin{abstract}
Alat
Jangka sorong dan pita ukur sebagai alat pengukur, kamera sebagai alat dokumentasi, timbangan sebagai alat pengukur bobot badan puyuh, pisau sebagai alat untuk memotong dan membedah, alat tulis untuk menulis data, serta satu unit komputer yang dilengkapi program Statistical Package for the Social Science (SPSS) untuk membantu pengolahan data.
\end{abstract}

\section{Metode Penelitian}

Metode penelitian yang digunakan adalah metode deskriptif. Setiap organ tubuh bagian luar dan organ dalam diukur serta dilakukan pengamatan langsung terhadap sifat kualitatif warna bulu pada puyuh liar (Turnix suscitator atrogularis) dan puyuh domestikasi.

\section{Pengumpulan Data}

Bagian-bagian organ tubuh bagian luar yang diukur adalah panjang femur, panjang tibia, panjang tarsometatarsus, keliling tarsometarsus, jari terpanjang, panjang sayap, dan panjang maxilla, sedangkan organ-organ dalam yang diukur adalah paruh, leher, small intestinum atau usus halus, large intestinum atau usus besar, dan organ hati.

\section{Analisis Data}

Morfologi dan morfometrik diperoleh dengan menghitung nilai rataan, Standar Deviasi (SD), dan koefisien keragaman (KK) dari setiap peubah yang diamati dengan menggunakan Principal Component Analysis (PCA) atau Analisis Komponen Utama (AKU). AKU digunakan untuk mengidentifikasi morfometrik dan morfologi organ tubuh bagian luar dan dalam pada puyuh berdasarkan konformasi tubuh (ukuran dan bentuk). 
Model analisis data yang digunakan untuk organ tubuh bagian luar adalah sebagai berikut:

$$
Y_{p}=a_{1 p} X_{1}+a_{2 p} X_{2}+a_{3 p} X_{3}+a_{4 p} X_{4}+\ldots .+a_{n p} X_{n}
$$

Keterangan :

$\mathrm{Y}_{\mathrm{p}} \quad=$ komponen utama ke-p

$a_{1 p}, a_{2 p}, \ldots a_{n p}=$ vektor ciri/vektor Eigen ke-1,..., n pada komponen utama ke-p

$\mathrm{X}_{1}, \mathrm{X}_{2}, \ldots, \mathrm{X}_{\mathrm{n}}=$ peubah-peubah yang diamati yaitu:

(panjang femur, panjang tibia, panjang tarsometatarsus, keliling tarsometarsus, jari terpanjang, panjang sayap, dan panjang maxilla).

Model matematika yang digunakan untuk menganalisis organ tubuh bagian dalam adalah sebagai berikut:

$$
Y_{p}=a_{1 p} X_{1}+a_{2 p} X_{2}+a_{3 p} X_{3}+a_{4 p} X_{4}+\ldots .+a_{n p} X_{n}
$$

Keterangan :

$\mathrm{Y}_{\mathrm{p}} \quad=$ komponen utama ke-p

$\mathrm{a}_{1 \mathrm{p}}, \mathrm{a}_{2 \mathrm{p}}, \ldots \mathrm{a}_{\mathrm{np}}=$ vektor ciri/vektor Eigen ke-1,..., n pada komponen utama ke-p

$\mathrm{X}_{1}, \mathrm{X}_{2}, \ldots, \mathrm{X}_{\mathrm{n}}=$ peubah-peubah yang diamati yaitu:

(mulut, leher, proventrikulus, gizzard, small intestinum atau usus halus, large intestinum atau usus besar, hati)

Model analisis yang digunakan untuk sifat kualitatif warna bulu adalah menggunakan rumus frekuensi relatif.

$$
\mathrm{Fr}=\frac{\mathrm{x}}{\mathrm{n}} \times 100 \%
$$

\section{Keterangan :}

$\mathrm{Fr} \quad=$ frekuensi relatif $(\%)$

$\mathrm{x} \quad=$ jumlah sampel dengan warna tertentu (ekor)

$\mathrm{n} \quad=$ jumlah sampel keseluruhan (ekor)

\section{Pemilihan sampel}

Sampel yang diteliti adalah burung puyuh liar (Turnix suscitator atrogularis) dan puyuh domestikasi yang telah mengalami dewasa tubuh. 


\section{HASIL DAN PEMBAHASAN}

\section{Ukuran-ukuran Linier pada Puyuh Liar (Turnix suscitator atrogularis)}

Pengukuran dilakukan terhadap 20 ekor puyuh liar (Turnix suscitator atrogularis) masing-masing 10 ekor jantan dan 10 ekor betina. Ukuran bagian-bagian tubuhnya menunjukkan perbedaan pada setiap organ luar dan dalam. Selain itu, perbedaan juga tampak pada masingmasing organ jantan dan betina. Ukuran-ukuran tubuh bagian luar pada puyuh liar dapat dilihat pada Tabel 1 berikut.

Tabel 1.Ukuran-ukuran linear organ luar pada puyuh liar

\begin{tabular}{lcccc}
\hline \multirow{2}{*}{\multicolumn{1}{c}{ Variabel }} & \multicolumn{2}{c}{ Jantan } & \multicolumn{2}{c}{$\begin{array}{c}\text { Betina } \\
(\mathrm{n}=10 \text { ekor })\end{array}$} \\
\cline { 2 - 5 } & $\bar{X} \pm \mathrm{SD}(\mathrm{cm})$ & $\mathrm{KK}(\%)$ & $\bar{X} \pm \mathrm{SD}(\mathrm{cm})$ & $\mathrm{KK}(\%)$ \\
\hline Panjang femur $\left(\mathrm{X}_{1}\right)$ & $3,17 \pm 0,13$ & 4,10 & $3,59 \pm 0,08$ & 2,22 \\
Panjang tibia $\left(\mathrm{X}_{2}\right)$ & $3.92 \pm 0,07$ & 1,78 & $4,31 \pm 0,08$ & 1,85 \\
Panjang Tarsometatarsus $\left(\mathrm{X}_{3}\right)$ & $2,69 \pm 0,15$ & 5,57 & $2,98 \pm 0,10$ & 3,35 \\
Keliling tarsometatarsus $\left(\mathrm{X}_{4}\right)$ & $1,13 \pm 0,04$ & 3,53 & $1,24 \pm 0,05$ & 4,03 \\
Jari ketiga $\left(\mathrm{X}_{5}\right)$ & $1,74 \pm 0,13$ & 7,47 & $1,22 \pm 0,04$ & 3,27 \\
Panjang sayap $\left(\mathrm{X}_{6}\right)$ & $3,22 \pm 0,13$ & 4,03 & $3,39 \pm 0,08$ & 2,35 \\
Panjang maxilla $\left(\mathrm{X}_{7}\right)$ & $1,85 \pm 0,11$ & 5,94 & $2,16 \pm 0,05$ & 2,31 \\
\hline
\end{tabular}

Ket : $\bar{X}=$ Rataan, $\mathrm{SD}=$ Standart Deviasi, $\mathrm{KK}=$ Koefisien Keragaman, $\mathrm{n}=$ Jumlah sampel

Berdasarkan Tabel 1 dapat dilihat perbedaan ukuran-ukuran linear organ tubuh bagian luar pada puyuh liar. Organ luar jantan memiliki ukuran tubuh yang lebih kecil dibandingkan organ luar betina. Koefisien keragaman terendah organ luar jantan terletak pada tibia yaitu $1,78 \%$ dan koefisien keragaman tertinggi terletak pada jari ketiga yaitu 7,47\%. Koefisien keragaman terendah pada organ luar betina terletak pada panjang tibia yaitu $1,85 \%$ dan koefisien keragaman tertinggi terletak pada keliling tarsometatarsus yaitu 4,03\%.

Perbedaan pada masing organ-organ tubuh juga tampak pada ukuran organ dalam puyuh liar. Perbedaan tampak pada masing-masing organ jantan dan betina seperti yang terlihat pada Tabel 2. Berdasarkan Tabel 2 dapat dilihat perbedaan ukuran-ukuran linear organ dalam pada puyuh liar. Organ dalam jantan memiliki ukuran tubuh yang lebih kecil dibandingkan organ dalam betina. Koefisien keragaman terendah organ dalam jantan terletak pada usus besar yaitu 
sebesar 4,54\% dan koefisien keragaman tertinggi terletak pada lehernya yaitu sebesar 7,54\%. Koefisien keragaman terendah organ dalam betina adalah usus halus yaitu 4,07\% dan koefisien keragaman tertinggi adalah leher yaitu $7,10 \%$.

Tabel 2. Ukuran-ukuran linear organ dalam puyuh liar

\begin{tabular}{lcccc}
\hline \multirow{2}{*}{ Variabel } & \multicolumn{2}{c}{$\begin{array}{c}\text { Jantan } \\
\text { (n=10 ekor) }\end{array}$} & \multicolumn{2}{c}{$\begin{array}{c}\text { Betina } \\
(\mathrm{n}=10 \text { ekor })\end{array}$} \\
\cline { 2 - 5 } & $\bar{X} \pm \mathrm{SD}(\mathrm{cm})$ & $\mathrm{KK}(\%)$ & $\bar{X} \pm \mathrm{SD}(\mathrm{cm})$ & $\mathrm{KK}(\%)$ \\
\hline Paruh $\left(\mathrm{X}_{1}\right)$ & $1,79 \pm 0,12$ & 6,70 & $1,89 \pm 0,12$ & 6,34 \\
Leher $\left(\mathrm{X}_{2}\right)$ & $1,59 \pm 0,12$ & 7,54 & $1,69 \pm 0,12$ & 7,10 \\
Usus besar $\left(\mathrm{X}_{3}\right)$ & $3,08 \pm 0,14$ & 4,54 & $3,18 \pm 0,14$ & 4,40 \\
Usus halus $\left(\mathrm{X}_{4}\right)$ & $20,30 \pm 0,94$ & 4,63 & $20,85 \pm 0,85$ & 4,07 \\
Hati $\left(\mathrm{X}_{5}\right)$ & $1,12 \pm 0,07$ & 6,25 & $1,21 \pm 0,07$ & 5,78 \\
\hline
\end{tabular}

Ket : $\bar{X}=$ Rataan, $\mathrm{SD}=$ Standart Deviasi, $\mathrm{KK}=$ Koefisien Keragaman, $\mathrm{n}=$ Jumlah sampel

Secara umum, puyuh liar jantan memiliki ukuran linear organ luar dan dalam yang lebih kecil dibandingkan pada puyuh liar betina. Hal ini sesuai dengan pernyataan dari Fadly (2013) yang menyatakan bahwa secara genetis puyuh liar (Turnix suscitator atrogularis) memiliki ukuran tubuh yang jauh lebih kecil dibandingkan puyuh jenis lainnya. Ukuran tubuh tersebut juga berbeda pada puyuh jantan dan betina. Hal ini sesuai dengan pernyataan dari Partodihardjo (1990) yang menyatakan bahwa pada beberapa ternak unggas, organ jantan memiki ukuran yang lebih kecil daripada organ betina.

\section{Ukuran-ukuran Linier pada Puyuh Domestikasi (Coturnix-coturnix japonica)}

Pengukuran dilakukan terhadap 20 ekor puyuh domestikasi (Coturnix-coturnix japonica) masing-masing 10 ekor jantan dan 10 ekor betina. Ukuran bagian-bagian tubuhnya menunjukkan perbedaan pada setiap organ luar dan dalam. Selain itu, perbedaan juga tampak pada masing-masing organ jantan dan betina. Ukuran-ukuran tubuh bagian luar pada puyuh domestikasi dapat dilihat pada Tabel 3 di bawah.

Berdasarkan Tabel 3 dapat dilihat perbedaan ukuran-ukuran linear organ luar pada puyuh domestikasi. Koefisien keragaman terendah organ luar jantan terletak pada sayap yaitu 1,88\% dan keragaman tertinggi terletak pada keliling tarsometatarsus yaitu sebesar 8,69\%. Koefisien 
keragaman terendah organ luar betina terletak pada femur yaitu 3,53\% dan koefisien keragaman tertinggi terletak pada keliling tarsometatarsus yaitu $8,27 \%$.

Tabel 3. Ukuran-ukuran linear organ luar puyuh domestikasi

\begin{tabular}{|c|c|c|c|c|}
\hline \multirow[t]{2}{*}{ Variabel } & \multicolumn{2}{|c|}{$\begin{array}{c}\text { Jantan } \\
(\mathrm{n}=10 \text { ekor })\end{array}$} & \multicolumn{2}{|c|}{$\begin{array}{c}\text { Betina } \\
(\mathrm{n}=10 \text { ekor })\end{array}$} \\
\hline & $\begin{array}{l}\text { Hasil pengukuran } \\
\bar{X} \pm \mathrm{SD}(\mathrm{cm})\end{array}$ & $\begin{array}{l}\mathrm{KK} \\
(\%)\end{array}$ & $\begin{array}{l}\text { Hasil pengukuran } \\
\bar{X} \pm \mathrm{SD}(\mathrm{cm})\end{array}$ & $\begin{array}{l}\mathrm{KK} \\
(\%)\end{array}$ \\
\hline Panjang femur $\left(\mathrm{X}_{1}\right)$ & $3,83 \pm 0,08$ & 2,08 & $4,24 \pm 0,15$ & 3,53 \\
\hline Panjang tibia $\left(\mathrm{X}_{2}\right)$ & $4,85 \pm 0,10$ & 2,06 & $5,09 \pm 0,20$ & 3,92 \\
\hline Panjang Tarsometatarsus $\left(\mathrm{X}_{3}\right)$ & $2,25 \pm 0,10$ & 4,44 & $2,50 \pm 0,11$ & 4,40 \\
\hline Keliling tarsometatarsus $\left(\mathrm{X}_{4}\right)$ & $1,15 \pm 0,10$ & 8,69 & $1,45 \pm 0,12$ & 8,27 \\
\hline Jari ketiga $\left(\mathrm{X}_{5}\right)$ & $2,16 \pm 0,09$ & 4,16 & $2,43 \pm 0,10$ & 4,11 \\
\hline Panjang sayap $\left(\mathrm{X}_{6}\right)$ & $9,55 \pm 0,18$ & 1,88 & $10,75 \pm 0,63$ & 5,86 \\
\hline Panjang maxilla $\left(\mathrm{X}_{7}\right)$ & $2,50 \pm 0,06$ & 2,40 & $2,50 \pm 0,11$ & 4,40 \\
\hline
\end{tabular}

Ket $: \bar{X}=$ Rataan, $\mathrm{SD}=$ Standart Deviasi, $\mathrm{KK}=$ Koefisien Keragaman, $\mathrm{n}=$ Jumlah sampel

Perbedaan pada masing organ-organ tubuh juga tampak pada ukuran-ukuran organ dalam puyuh domestikasi . Perbedaan dapat dilihat pada masing-masing organ jantan dan betina seperti yang terlihat pada Tabel 4 berikut ini.

Tabel 4. Ukuran-ukuran linear organ dalam puyuh domestikasi

\begin{tabular}{lcccc}
\hline \multirow{2}{*}{ Variabel } & \multicolumn{2}{c}{$\begin{array}{c}\text { Jantan } \\
(\mathrm{n}=10 \text { ekor })\end{array}$} & \multicolumn{2}{c}{$\begin{array}{c}\text { Betina } \\
(\mathrm{n}=10 \text { ekor })\end{array}$} \\
\cline { 2 - 5 } & $\bar{X} \pm \mathrm{SD}(\mathrm{cm})$ & $\mathrm{KK}(\%)$ & $\bar{X} \pm \mathrm{SD}(\mathrm{cm})$ & $\mathrm{KK}(\%)$ \\
\hline Paruh $\left(\mathrm{X}_{1}\right)$ & $2,47 \pm 0,10$ & 4,04 & $2,57 \pm 0,10$ & 3,89 \\
Leher $\left(\mathrm{X}_{2}\right)$ & $1,78 \pm 0,13$ & 7,30 & $1,88 \pm 0,13$ & 6,91 \\
Usus besar $\left(\mathrm{X}_{3}\right)$ & $3,37 \pm 0,26$ & 7,71 & $3,47 \pm 0,26$ & 7,49 \\
Usus halus $\left(\mathrm{X}_{4}\right)$ & $22,75 \pm 2,71$ & 11,91 & $23,40 \pm 2,87$ & 12,26 \\
Hati $\left(\mathrm{X}_{5}\right)$ & $1,57 \pm 0,09$ & 5,73 & $1,67 \pm 0,09$ & 5,38 \\
\hline
\end{tabular}

Ket : $\bar{X}=$ Rataan, $\mathrm{SD}=$ Standart Deviasi, $\mathrm{KK}=$ Koefisien Keragaman, $\mathrm{N}=$ Jumlah sampel

Berdasarkan Tabel 4 dapat dilihat perbedaan ukuran-ukuran linear organ dalam puyuh domestikasi. Koefisien keragaman terendah organ dalam jantan terletak pada paruh yaitu 4,04\% dan koefisien keragaman tertinggi terletak pada usus halusnya yaitu 11,91\%. Koefisien 
keragaman terendah organ dalam betina terletak pada paruh dan koefisien keragaman tertinggi terletak pada usus halus yaitu $12,26 \%$.

Secara umum, organ luar dan dalam pada puyuh domestikasi jantan menunjukkan ukuran yang lebih kecil dibandingkan pada betina. Hal ini sesuai dengan pernyataan dari Nugroho (1981) yang menyatakan bahwa secara genetis puyuh domestikasi memiliki ukuran tubuh yang lebih besar dibandingkan puyuh liar. Puyuh domestikasi dan puyuh liar memiliki cara hidup dan pemeliharaan yang sangat berbeda. Hal ini sesuai dengan pernyataan dari Listoyowati dan Roospitasari (1992) yang menyatakan bahwa puyuh domestikasi telah mengalami perlakuan dan campur tangan manusia secara langsung di dalam budidayanya sedangkan puyuh liar sebahagian besar masih hidup sendiri di alam bebas. Hal ini juga menjadi faktor yang mempengaruhi perbedaan bentuk dan ukuran kedua burung puyuh.

\section{Ukuran dan Bentuk Tubuh Puyuh Liar (Turnix suscitator atrogularis) dan Puyuh Domestikasi berdasarkan Analisis Komponen Utama.}

Hasil olahan data berdasarkan Analisis Komponen Utama (AKU) menghasilkan perbedaaan morfologi dan morfometrik puyuh liar dan domestikasi. Perbedaan tersebut dapat dinyatakan di dalam persamaan ukuran dan bentuk. Persamaan ini dibuat berdasarkan nilai score component coefisien matriks yang diturunkan berdasarkan hasil olahan data menggunakan Analisis Komponen Utama.

\section{a. Persamaan Ukuran dan Bentuk Tubuh dengan Keragaman total dan Nilai Eigen pada Puyuh liar}

Persamaan ukuran dan bentuk organ luar dengan keragaman total dan nilai Eigen dapat dilihat pada Tabel 5.

Tabel 5. Persamaan ukuran dan bentuk organ luar dengan keragaman total dan nilai Eigen pada puyuh liar

\begin{tabular}{ccc}
\hline Persamaan & $\begin{array}{c}\text { Keragaman } \\
\text { total }(\%)\end{array}$ & $\begin{array}{c}\text { Nilai } \\
\text { Eigen }\end{array}$ \\
\hline Ukuran $=0,227 \times 1+0,179 \times 2+0,147 \times 3+0,020 \times 4+$ & 91,81 & 0,25 \\
$0,277 \times 5+0,066 \times 6+0,126 \times 7$ & & \\
Bentuk $=0,223 \times 1-0,252 \times 2+0,573 \times 3+0,016 \times 4-$ & 88,28 & 6,18 \\
$1,378 \times 5+0,805 \times 6+0,143 \times 7$ & & \\
\hline
\end{tabular}


Berdasarkan Tabel 5 dapat diketahui bahwa keragaman total ukuran tubuh sebesar 91,81\% yang menggambarkan nilai keragaman tertinggi. Nilai Eigen pada persamaan ukuran tubuh sebesar 0,25. Penciri utama ukuran organ luar pada puyuh liar adalah jari ketiga dengan vektor sebesar 0,277. Keragaman total bentuk tubuh didapatkan sebesar 88,28\% dengan nilai Eigen 6,18. Penciri utama bentuk organ luar pada puyuh liar adalah sayap dengan nilai vektor Eigen 0,805. Hasil ini menunjukkan bahwa peningkatan ukuran jari ketiga akan menaikkan ukuran organ luar dan peningkatan panjang sayap akan menaikkan skor bentuk organ luar puyuh liar.

Persamaan ukuran dan bentuk organ luar pada puyuh liar memiliki perbedaan dengan persamaan ukuran dan bentuk pada organ dalam. Persamaan juga menunjukkan keragaman total dan nilai eigen yang berbeda yang dapat dilihat pada Tabel 6 .

Tabel 6. Persaman ukuran dan bentuk organ dalam dengan keragaman total dan nilai Eigen pada puyuh liar

\begin{tabular}{|c|c|c|}
\hline Persamaan & $\begin{array}{c}\text { Keragaman } \\
\text { total }(\%)\end{array}$ & $\begin{array}{l}\text { Nilai } \\
\text { Eigen }\end{array}$ \\
\hline $\begin{aligned} \text { Ukuran }= & 0,018 \times 1+0,018 \times 2+0,938 \times 3+0,025 \mathrm{X} 4+ \\
& 0,006 \mathrm{X} 5\end{aligned}$ & 98,70 & 0,90 \\
\hline $\begin{aligned} \text { Bentuk }= & 0,840 \mathrm{X} 1+0,840 \mathrm{X} 2-2,407 \mathrm{X} 3+0,685 \mathrm{X} 4+ \\
& 0,291 \mathrm{X} 5\end{aligned}$ & 82,48 & 4,12 \\
\hline
\end{tabular}

Berdasarkan Tabel 6 dapat dilihat keragaman total ukuran organ dalam puyuh liar adalah 98,70\% yang menggambarkan nilai keragaman tertinggi. Nilai Eigen pada persamaan ukuran tubuh sebesar 0,90 . Penciri utama ukuran organ dalam pada puyuh liar adalah usus halus dengan vektor sebesar 0,938 . Keragaman total pada bentuk tubuh didapatkan sebesar 82,48 \% dengan nilai Eigen 4,12. Penciri utama bentuk tubuh bagian dalam pada puyuh liar adalah panjang paruh dan leher dengan vektor Eigen 0,840 . Hasil ini menunjukkan bahwa peningkatan ukuran usus halus akan menaikkan ukuran organ dalam dan peningkatan panjang paruh dan leher akan menaikkan skor bentuk organ dalam puyuh liar.

Berdasarkan Tabel 5 dan 6 di atas maka diperoleh rekapitulasi penciri utama ukuran dan bentuk organ luar dan dalam pada puyuh liar yang dapat dilihat dari Tabel 7 di bawah.

Tabel 7. Rekapitulasi penciri utama ukuran dan bentuk organ luar dan dalam pada puyuh liar 


\begin{tabular}{ccc}
\hline $\begin{array}{c}\text { Ukuran dan Bentuk } \\
\text { Tubuh }\end{array}$ & Penciri Ukuran & Penciri Bentuk \\
\hline Organ Luar & $\bar{X} \pm \mathrm{SD}(\mathrm{cm})$ & Panjang Sayap \\
& Jari ketiga & $(3,30 \pm 0,14)$ \\
Organ Dalam & $(1,97 \pm 0,24)$ & Panjang paruh dan leher \\
& Panjang usus halus & $(3,13 \pm 0,15)$ \\
\hline
\end{tabular}

Berdasarkan hasil penelitian, dapat diketahui juga bahwa terdapat korelasi positif dan nyata antara skor ukuran dan bobot tubuh burung puyuh liar. Hal ini sesuai dengan pernyataan dari Hanibal (2008) yang menyatakan bahwa peningkatan ukuran tubuh akan mengakibatkan peningkatan bobot tubuh. Demikian sebaliknya, penurunan ukuran tubuh akan mengakibatkan penurunan bobot tubuh.

\section{b. Persamaan Ukuran dan Bentuk Tubuh dengan Keragaman total dan Nilai Eigen pada Puyuh domestikasi}

Persamaan ukuran dan bentuk organ luar dengan keragaman total dan Eigen tampak pada Tabel 8 .

Tabel 8. Persaman ukuran dan bentuk organ luar dengan keragaman total dan nilai eigen pada puyuh domestikasi

\begin{tabular}{ccc}
\hline Persamaan & $\begin{array}{c}\text { Keragaman } \\
\text { total }(\%)\end{array}$ & $\begin{array}{c}\text { Nilai } \\
\text { Eigen }\end{array}$ \\
\hline Ukuran $=0,143 \times 1+0,152 \times 2+0,152 \times 3+0,152 \times 4$ & 93,50 & 6,54 \\
$+0,146 \times 5+0,144 \times 6+0,143 \times 7$ & & \\
Bentuk $=\begin{array}{cc}-1,357 \times 1-0,195 \times 2-0,195 \times 3-0,195 \times 4- \\
0,283 \times 5+0,935 \times 6+1,321 \times 7\end{array}$ & 3,06 & 0,21 \\
\hline
\end{tabular}

Berdasarkan Tabel 8 dapat diketahui bahwa keragaman total dari persamaan ukuran organ dalam adalah 93,50\% yang menggambarkan nilai keragaman tertinggi. Nilai Eigen pada persamaan ukuran tubuh sebesar 6,54. Penciri utama ukuran organ tubuh bagian luar adalah panjang femur dan tibia dengan vektor sebesar 0,152. Keragaman total pada bentuk tubuh sebesar 3,06\% dengan nilai Eigen 0,21. Penciri utama bentuk organ luar adalah panjang maxilla dengan vektor Eigen 1,321. Hasil ini menunjukkan bahwa peningkatan ukuran panjang femur dan tibia akan menaikkan ukuran organ luar dan peningkatan panjang maxilla akan menaikkan skor bentuk organ luar puyuh domestikasi.

Persamaan ukuran dan bentuk organ luar pada puyuh domestikasi memiliki perbedaan dengan persamaan ukuran dan bentuk organ dalam. Persamaan juga menunjukkan keragaman 
total dan nilai eigen yang berbeda yang dapat dilihat pada Tabel 9 berikut.

Tabel 9. Persamaan ukuran dan bentuk organ dalam dengan keragaman total dan nilai Eigen pada puyuh domestikasi

\begin{tabular}{|c|c|c|}
\hline Persamaan & $\begin{array}{c}\text { Keragaman } \\
\text { total }(\%)\end{array}$ & $\begin{array}{l}\text { Nilai } \\
\text { Eigen }\end{array}$ \\
\hline $\begin{aligned} \text { Ukuran }= & 0,361 \times 1+0,125 \times 2+0,260 \times 3+ \\
& 0,323 \times 4+0,362 \times 5\end{aligned}$ & 44,61 & 2,23 \\
\hline $\begin{aligned} \text { Bentuk }= & 0,272 \mathrm{X} 1+0,279 \mathrm{X} 2-0,432 \mathrm{X} 3-0,357 \mathrm{X} 4 \\
& +0,261 \mathrm{X} 5\end{aligned}$ & 37,42 & 1,87 \\
\hline
\end{tabular}

Berdasarkan Tabel 9 dapat dilihat keragaman total dari persamaan ukuran tubuh sebesar $44,61 \%$ yang menggambarkan nilai keragaman tertinggi. Nilai Eigen pada persamaan ukuran tubuh sebesar 2,23. Penciri utama ukuran organ dalam adalah hati dengan vektor sebesar 0,362 . Keragaman total pada bentuk tubuh didapatkan sebesar 37,42\% dengan nilai Eigen 1,87. Penciri utama bentuk organ dalam adalah panjang leher dengan vektor Eigen sebesar 0,279. Hasil ini menunjukkan bahwa peningkatan ukuran organ hati akan menaikkan ukuran organ dalam dan peningkatan panjang leher akan menaikkan skor bentuk organ dalam puyuh domestikasi.

Berdasarkan Tabel 8 dan 9 di atas maka diperoleh rekapitulasi penciri utama ukuran dan bentuk organ luar dan dalam pada puyuh liar yang dapat dilihat dari Tabel 10 di bawah.

Tabel 10. Rekapitulasi penciri ukuran dan bentuk organ tubuh bagian luar dan dalam puyuh domestikasi

\begin{tabular}{ccc}
\hline $\begin{array}{c}\text { Ukuran dan Bentuk } \\
\text { Tubuh }\end{array}$ & Penciri Ukuran & Penciri Bentuk \\
\hline Organ Luar & $\bar{X} \pm \mathrm{SD}(\mathrm{cm})$ & Panjang Maxilla \\
& Panjang Femur & $(2,50 \pm 0,45)$ \\
& $(4,03 \pm 0,24)$ & \\
Panjang Tibia & \\
Organ Dalam & $(4,97 \pm 0,20)$ & Panjang leher \\
& Hati & $(1,83 \pm 0,14)$ \\
\hline
\end{tabular}

Berdasarkan hasil penelitian, dapat diketahui juga bahwa terdapat korelasi positif dan nyata antara skor ukuran dan bobot tubuh burung puyuh domestikasi. Hal ini sesuai dengan pernyataan dari Annehira (2012) yang menyatakan bahwa peningkatan ukuran tubuh akan mengakibatkan peningkatan bobot tubuh. Demikian sebaliknya, penurunan ukuran tubuh akan 
mengakibatkan penurunan bobot tubuh.

Sifat Kualitatif Warna Bulu pada Burung Puyuh Liar (Turnix suscitator atrogularis) dan Puyuh Domestikasi

Berdasarkan sampel burung puyuh liar dan domestikasi yang diamati dapat dilihat perbedaan variasi warna bulu pada masing-masing kedua jenis puyuh. Perbedaan tersebut dapat kita lihat pada gambar berikut ini.

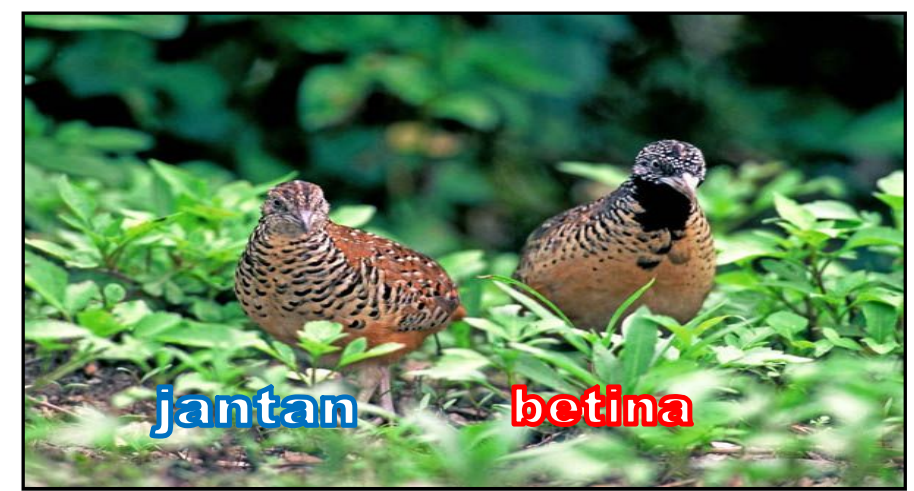

Gambar 1. Puyuh liar (Turnix suscitator atrogularis)

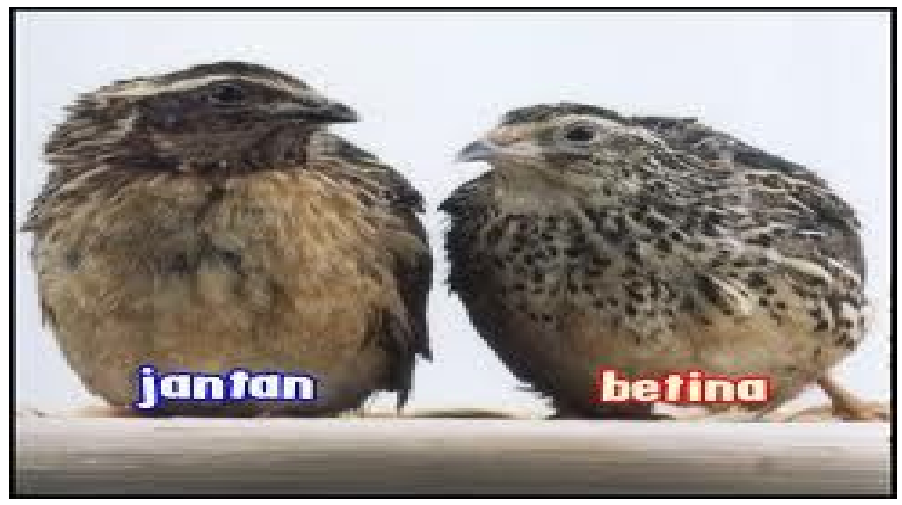

Gambar 2. Puyuh Domestikasi (Coturnix-coturnix japonica)

Berdasarkan sifat kualitatif warna bulu yang diamati pada 20 ekor sampel puyuh liar dan domestikasi dapat diketahui bahwa terdapat perbedaan warna bulu pada masing-masing puyuh. Karakteristik sifat-sifat kualitatif warna bulunya dapat dilihat pada Tabel 11. 
Tabel 11. Karakteristik sifat-sifat kualitatif warna bulu pada puyuh liar dan domestikasi

\begin{tabular}{|c|c|c|c|c|c|}
\hline \multirow[t]{2}{*}{ Sifat kualitatif } & \multicolumn{2}{|c|}{ Liar } & \multicolumn{2}{|c|}{ Domestikasi } & \multirow{2}{*}{$\begin{array}{l}\text { Frekuensi } \\
\text { relatif }(\%)\end{array}$} \\
\hline & Jantan & Betina & Jantan & Betina & \\
\hline \multicolumn{6}{|l|}{ Bagian kepala: } \\
\hline - berbintik putih dan hitam & - & 10 & - & - & 100 \\
\hline - bergaris cokelat dan kuning & 10 & - & 10 & 10 & 100 \\
\hline \multicolumn{6}{|l|}{ Bagian paruh: } \\
\hline - berwarna abu-abu & - & - & 10 & 10 & 100 \\
\hline - berwarna kuning & 10 & 10 & - & - & 100 \\
\hline \multicolumn{6}{|l|}{ Bagian leher: } \\
\hline - bertotol kuning kecokelatan & 10 & - & - & - & 100 \\
\hline - bertotol hitam & - & 10 & - & - & 100 \\
\hline - berwarna coklat gelap & - & - & 10 & - & 100 \\
\hline - berwarna coklat muda & - & - & - & 10 & 100 \\
\hline \multicolumn{6}{|l|}{ Bagian dada: } \\
\hline - bertotol kuning dan hitam & 10 & 10 & - & 10 & 100 \\
\hline - berwarna cokelat & - & - & 10 & - & 100 \\
\hline \multicolumn{6}{|l|}{ Bagian pungung: } \\
\hline - bertotol cokelat dan hitam & 10 & 10 & - & - & 100 \\
\hline - bertotol cokelat dan kuning & - & - & 10 & 10 & 100 \\
\hline \multicolumn{6}{|l|}{ Bagian perut: } \\
\hline - berwarna kuning & 10 & 10 & - & - & 100 \\
\hline - berwarna cokelat muda & - & - & 10 & 10 & 100 \\
\hline \multicolumn{6}{|l|}{ Bagian sayap: } \\
\hline - bertotol kuning dan hitam & 10 & 10 & - & - & 100 \\
\hline - bertotol kuning dan cokelat & - & - & 10 & 10 & 100 \\
\hline \multicolumn{6}{|l|}{ Bagian ekor: } \\
\hline - berwarna cokelat tua & 10 & 10 & - & - & 100 \\
\hline - berwarna cokelat muda & - & - & 10 & 10 & 100 \\
\hline \multicolumn{6}{|l|}{ Bagian kaki: } \\
\hline - berwarna kuning & - & - & 10 & 10 & 100 \\
\hline - berwarna abu-abu & 10 & 10 & - & - & 100 \\
\hline
\end{tabular}

Ket : (N=Jumlah sampel pada puyuh liar dan domestikasi sebanyak 20 ekor)

Berdasarkan Tabel 11 dapat diketahui bahwa sifat-sifat kualitatif warna bulu pada puyuh liar jantan dan betina secara umum menunjukkan warna yang seragam pada bagian-bagian tubuhnya. Persentase frekuensi relatif warna bulunya menunjukkan persentase yang sama yaitu $100 \%$. Perbedaan yang paling jelas terdapat pada bagian leher, paruh, dan kakinya. Puyuh liar jantan memiliki leher berwarna kuning kecokelatan, sedangkan betina berwarna hitam. Puyuh liar memiliki paruh dan kaki berwarna abu-abu sedangkan puyuh domestikasi memilki paruh dan kaki berwarna kuning 
Pengambilan sampel puyuh liar yang tertuju pada satu daerah tertentu menunjukkan variasi warna bulu yang hampir seragam. Selain itu, variasi warna ini juga dipengaruhi oleh faktor genetis dan lingkungan. Hal ini sesuai dengan pernyataan dari Rezah (2012) yang menyatakan bahwa variasi warna bulu merupakan karakteristik genetik yang ekspressinya dikontrol oleh beberapa gen di dalam tubuh. Selain itu, faktor lingkungan juga memberikan pengaruh di dalam pewarisan warna bulu pada puyuh. Hal ini sesuai dengan pernyataan dari Noor (1996) yang menyatakan bahwa faktor genetik dan lingkungan adalah kedua faktor utama di dalam pewarisan sifat-sifat pada ternak.

\section{KESIMPULAN}

Penciri utama ukuran organ luar puyuh liar (Turnix suscitator atrogularis) adalah panjang jari ketiga dan penciri utama bentuk organ luar adalah panjang sayap. Penciri ukuran utama organ dalam adalah panjang usus halus dan penciri bentuk utama adalah panjang paruh dan leher.

Penciri utama ukuran organ puyuh domestikasi adalah panjang femur dan tibia. Penciri bentuk utama organ luar adalah panjang maxilla. Penciri ukuran utama organ dalam adalah organ hati dan penciri utama bentuk adalah panjang leher. Sifat kualitatif warna bulu pada puyuh liar berbeda dengan puyuh domestikasi. Perbedaan juga tampak pada organ jantan dan betina. Puyuh liar jantan memiliki leher berwarna kuning kecokelatan, sedangkan betina berwarna hitam. Puyuh domestikasi jantan memiliki leher berwarna cokelat tua sedangkan betina berwarna cokelat muda. Puyuh liar memiliki paruh dan kaki berwarna abu-abu sedangkan puyuh domestikasi memilki paruh dan kaki berwarna kuning.

\section{DAFTAR PUSTAKA}

Annehira. 2012. Beternak Burung Puyuh. http:// www. annehira. com.

[Diakses pada tanggal 15 maret 2013 pukul 20.00 wib].

Fadly, M. 2013. Mengenal Hewan dan Tumbuhan Asli Indonesia. Penebar Swadaya. Jakarta.

Insani, G. A. 2007. Sejarah dan Ciri- cirri Puyuh. http://www. Chickaholic. wordpress. com. [ Diakses pada tanggal 17 maret 2013 pukul $11.00 \mathrm{wib}]$.

Listiyowati, E. dan Roospitasari, K. 1992. Tatalaksana dan Budidaya Puyuh Secara Komersial. Penebar Swadaya, Jakarta

Noor, R. R. 1996. Genetika Ternak. Penebar Swadaya, Jakarta 
Nugroho, M. 1981. Beternak Burung Puyuh. Fakultas Kedokteran Hewan dan Peternakan Universitas Udayana, Bali.

Partodihardjo, S. 1990. Ilmu Reproduksi Hewan. Penerbit Mutiara, Jakarta.

Rasyaf, M. 1985. Memelihara Burung Puyuh. Penerbit Kanisius, Yogyakarta.

Rezah. Z. 2012. Warna Bulu Pada Burung. http:// www. rezahzulfikar. blogspot.com [Diakses pada tanggal 18 maret 2013 pukul $09.00 \mathrm{wib}$ ].

Hanibal, M. V. 2008. Ukuran dan Bentuk serta Pendugaan Berdasarkan Ukuran Tubuh Domba Silangan Lokal Garut Jantan di Kabupaten Tasikmalaya. Skripsi. Fakultas Peternakan Institut Pertanian Bogor, Bogor. 